\title{
THE PATTERN OF STUDENTS' CHARACTER COACHING IN ANTICIPATING INTOLERANCE BELIEF IN ISLAMIC RELIGIOUS UNIVERSITIES IN SULAWESI BARAT
}

\author{
Muliadi \\ STAIN Majene \\ Jl. Balai Latihan Kerja Kel. Totoli Kec. Banggae Kab. Majene Indonesia \\ Email:mmulqi73@gmail.com \\ A. Zamakhsyari Baharuddin \\ STAIN Majene \\ Jl. Balai Latihan Kerja Kel. Totoli Kec. Banggae Kab. Majene Indonesia \\ Email: ansamad90@gmail.com
}

Article received July $30^{\text {th }}, 2021$; Article revised September $19^{\text {th }}, 2021$; Article approved October $22^{\text {th }}, 2021$

\begin{abstract}
This study aimed to determine the role of Islamic Religious Universities (PTKI) in West Sulawesi in establishing the character as an effort in student coaching to anticipate intolerance belief and radicalism. The research type and method used was qualitative. This research is expected to be able to provide a systematic, thorough, and accurate description of the pattern of students coaching at PTKI in counteracting the radicalism in West Sulawesi. The data generated in this study are presented in a descriptive form. The research was conducted in 4 (four) PTKI namely STAIN Majene, STAIN DDI Majene, STAI Al-Azhary Mamuju, and IAI DDI Polman. The results showed that the strategy of students' character coaching of PTKI in West Sulawesi as an effort to anticipate the intolerant belief and radicalism refers to the Marten strategy which includes 3 (three) stages, namely: the identify the values, teach the values, and apply the values. In practice, the strategy which was implemented integratedly could successfully create a pattern of coaching in the form of training, consulting, mentoring, managing, and leading under the synergogy concept which leads to the strengthening of the national knowledge and the deepening the religious understanding.
\end{abstract}

Keywords: character coaching, anticipating intolerance, counteracting the radicalism

\section{INTRODUCTION}

$\mathrm{E}$ ducation should be one of the fundamental instruments in building the nation's character (nation and character building) amid diversity that became the main distinctive feature of Indonesia. (Mukhibat, 2015) As a nation that believes in one God, Indonesia allows the religion to have a contribution in practising state life, as well as being an important part within certain limits that can not be separated from national life.

In its development, Islamic religious education as stated in Law No. 20 of 2003 and PP No. 57 of 2007 is the compulsory subject in formal education, that its learning objective should be in line with the objectives of the state, namely building the noble personal character based on faith and piety, personality, noble character and make them good citizens, thus the Islamic religious education should be able to strengthen the civil values such as tolerance, freedom, justice and equality. (Saputra, 2018)

In this context, the pattern of diversity development based on inclusivism, pluralism and multiculturalism becomes crucial that it can be transformed into the religious attitude which is tolerant and inclusive to form a hanief religious paradigm pattern. Thus, it urges the reorientation of a religious education system that emphasizes the social contract of religious and public morality under the inclusivism framework.

Tolerance is needed to build a mutual understanding and appreciate the differences that exist, as well as being the entry point to create the circumstance opened for dialogue and interfaith harmony within the community. University students are considered as one of the groups that became an important supplement of community because they have 
great potential in creating a certain order. (Republik Indonesia, 2010, p. 3)

Ironically, the intolerant attitude is precisely displayed by those students. In fact, the education that they get should be able to turn them to be dignified humans, but in the reality, it seems that education has not been able to set the values that are meaningful for the students. In the formal education context at the higher education level, this condition is happening because the Indonesian education system puts more emphasis on the development of academics, while other nonacademic aspects as the main factor of character building have not yet been prioritized even they seem to be ignored. This indicates the weakness of our national education policy which is considered failed in integrating education and character development. (Zubaedi, 2011, p. 3)

The religious life increasingly becomes formalistic and symbolic only, that it is cannot convey the relation of ritual piety and social piety. (Soetanto, Aulanni'am, Guritno, \& Suharto, 2013, p. 2) That is to say, our national life has been signified by religious radicalism, especially the one which is developed in the Islamic environment. (Arif, 2016) The radicalization of religion which broke almost all over the world now turns out as the radicalization of Islamic ideology by some people who comprehend and interpret religious text radically. (Kisbiyanto, 2016) Thus, Indonesia as the country with the largest number of Muslims has a great responsibility to anticipate and cope with the deradicalization program for religious belief.

Deradicalisation of Islamic religious ideology obviously would be a task and concentration of scientists, experts, and practitioners at Islamic Religious Universities (PTKI). Therefore, PTKI as a centre of education and da'wah of Islam, requires competent professionals, including also the competence of lecturers in developing the vision, curriculum, and learning process that shows a moderate Islam. (Kisbiyanto, 2016) The value of Islamic teachings under the rahmatan lil 'alamin, tolerance, humanism, plurality, and multiculturalism are among the aspects that must be prioritized and considered by the lecturer to prevent the ideological- political nuance of the education. (Suharto \& Assagaf, 2014)

The PTKI world in this context should become the counter of the radical religious belief in this region. However, the ideology of radicalism and intolerance have been confirmed entering the PTKI powerfully and structurally through religious extracurricular activities, as well as the engagement with parties affiliated with the radical movement.

The portrait of the radicalism movement in PTKI has become public consumption. In 2011, Pepi Fernando, the alumnus of UIN Syarif Hidayutullah Jakarta, was suspected as the brain of the perpetrator behind the Serpong bomb attack. (Cahyani, 2011) Counterterrorism Special Detachment 88, as reported by the Kompas Daily in 2016, (Wismabrata, 2016) also arrested one student with the initials of KF in Surakarta, who was a student of the Islamic Banking Department at FEBI because allegedly involved in the network of the terrorist group in Bekasi. The IDN Times also published the news about a student of IAIN Tulungagung, East Java who was deported from Syria using the Turkish Airlines flight TK-056, along with several Indonesian Citizens from different regions because of its alleged involvement in the radical group Islamic State of Iraq and Syria (ISIS). (Rochmanuddin, 2018) The rise of cases that indicate students as the perpetrators of terror and sympathizers of the radical movement further confirms that PTKI is in a state of student emergency. In the meeting forum of the Student Organization Leaders (ORMAWA) in IAIN Bengkulu, Ruchman Basori as the Head of Student Affairs of Directorate of Islamic Higher Education (Diktis) stated that the finding of several bombs ready to explode and the culprit is indicated as a student, became the strong warning that the terrorists are targeting the intellectuals from higher education level. (Kontri, 2018)

Based on a national survey in 34 Provinces conducted by the Center for Islamic and Society Studies (PPIM) UIN Jakarta in 2017 showed that at the level of the attitudes/opinions, the students had a religious perception tended to be radical $(58.5 \%)$ and intolerant $(51.1 \%$ of internal intolerance, and 
$34.3 \%$ of external intolerance). (Saputra, 2018, p. 6)

The same thing was delivered by Brigadier General Baharuddin Djafar that "the radicalism potential in West Sulawesi has reached up to $54.5 \%$, this figure is being stronger", on the Deradicalisation Training for Millennial Generation that took place in Mamuju, West Sulawesi. (Amirullah, 2018)

The rise of intolerant beliefs among the students become a serious threat nowadays. Intolerance in educational institutions in Indonesia has been very worrying, especially in West Sulawesi, according to the head of the National Counter-Terrorism Agency (BNPT) of West Sulawesi, Mercy Sanusi who argued that the West Sulawesi region as the gold category region and the strategic path that connects Palu, Central Sulawesi, Makassar in South Sulawesi and Kalimantan. ("BNPT: Sulbar Rawan Jadi Persinggahan Teroris," 2018)

The radicalism problems that affect students in higher education, even just a small portion, can certainly have an impact on other students. Therefore, none of the campuses wants to get an award as a terrorist centre or educate the would-be terrorists. The emerging seeds need to be anticipated and measured in terms of their impact in the future. Approaches both persuasive and firmly way can surely be a consideration for other parties who are in the same region in order to anticipate those bad events in the future.

The case of intolerant belief in West Sulawesi threaten the 4 (four) of Islamic Religious Universities (PTKI) in that area namely State Islamic College (STAIN) of Majene, Islamic Institut (IAI) of Darul da'wah Wal Irsyad Polewali, Islamic College (STAI) of Darul da'wah Wal Irsyad Majene, and Islamic College (STAI) of Al-Azhary Mamuju that collectively accommodate around 5 (five) thousand students. Since these four PTKI are located in the strategic and tactical route of radical ideology, they are vulnerable to being affected by intolerant beliefs.

Based on the above description, this study examines the patterns and the form of student coaching in Islamic Religious Universities as an effort to anticipate the intolerant belief in West Sulawesi. The4 (four) local-based PTKI are chosen under the basic assumption that the transformation of religious education today puts more emphasis on indoctrination.

\section{Patterns of Student Coaching}

The pattern of coaching is an effort that is performed continuously and on an ongoing basis by the institutions to make students become better people and be able to actualize themselves both within the family and the community.

To coach is closely associated with education because it is an act that ultimately provides a form of education. Coaching is also almost the same with guidance and counselling. The pattern of coaching was formed to establish a daily relationship with learners which equipped with the action of the agency or institution to build the character of the learner so that it becomes a way or technique that is used by institutions or agencies in hosting the education and mentoring the learners to become a better person expected.

The coaching activities essentially aim to realize the changes in participants' behaviour. Changes in behaviour can be in the form of increased knowledge, expertise, skills, changes in attitudes and behaviour. Therefore, the objective of coaching is based on efforts to develop the cognitive, affective, and psychomotor of the learners. (Sudjana, 2010, p. 22)

Therefore, a mentor/student coach should promote ways that are educative, persuasive, and dialogic. With such an approach, the existence of coach/companion is no longer as a boss but rather a partner with the same level with the students, so that in running the role as educators, the companion looked at the students not only as an object but a subject who is involved in the educational process. (Sumaryanto, 2002)

In order to accommodate the interests of the coach/companion with the interests of the students, Mouton and Blake as narrated by Sumaryanto(2002) offered a Synergogy concept which was the alternative to the mentoring process.

Synergogy has derived from synorgos and agogus. In the Greek language, Synorgos means working together, while agogus has the meaning of leader (leader of) or 
coaches/companion. Thus, synergogy refer to the concept of having collaborative activities in a variety of teaching (working together for shared learning). (Sumaryanto, 2002)

In practice, the pattern of participatory will be very dominated by the synergogy approach where the role of the coach/companion is no longer central in the process of student development but rather a means of leadership learning for students in representing or delegating the role of the coach/companion. (Sinambela, 2002)

The technical for student coaching/mentoring process can be done by training, consulting, mentoring, managing, leading, and therapy, which is described in the following description:

1. Training is the process of giving information and knowledge about certain things that were taught by the expert of the material;

2. Consulting is the process of providing consultation in resolving the problems faced;

3. Mentoring is the process of supervision from a person who has mastered certain things and shared the knowledge with others in need;

4. Managing is the activity to manage people to be able to jointly achieve the goals of an organization;

5. Leading is the activity of bringing others with a similar vision to achieve the vision of the organization; and

\section{The Strategy of Student Character Education}

Lickona (1992, p. 12) shared the definition of character education as the earnest efforts to help someone understand, care about, and act under a foundation of ethical values. In his view, there are three elements contained in character education, namely knowing the good, desiring the good, and doing the good.

\section{Meanwhile, Ratna Megawangi}

(Megawani, 2007, p. 98) argued that character education is an effort to educate children so they can take the decision wisely and apply it in their lives so that they can contribute positively to the surrounding environment.

As a conclusion from the above definition, we can define that character education is the activity of internalization of cultural values and religion to form the student's personality that is reflected in the positive real action both for themselves and the environment.

In the grand design of character education, (Anwas, 2010, p. 258)character education is a process of acculturation and the empowerment of values at the educational level, family level, and society level.

The character education values developed based on the four pillars of the nation and became the umbrella of the development of the values. The four pillars are Pancasila, the 1945 constitution, the Unitary State of the Republic of Indonesia, Bhinneka Tunggal Ika. The values that are developed are those based on feeling processing, thinking processing, body processing, and sense and intention processing.

Feeling processing is related to the feeling of attitudes and beliefs/faith. Thinking processing is related to the process of reasoning in order to find and use knowledge in critical, creative, and innovative ways. Body processing is related to the process of perception, readiness, imitation, manipulation, and creation of new activities accompanied by sportsmanship. The sense and intention processing related to the willingness and creativity that are reflected in the awareness, imagery, and the creation of novelty. (Kesra, 2010, p. 21)

The function of character education that has been outlined by the Directorate of Higher Education is the formation and the development of potential, improvement and strengthening, as well as filtering. Those three functions are described as follows: (Zubaedi, 2011, p. 21)

1. Develop the potential of learners to think better, kindly, and behaved under the philosophy of life from Pancasila;

2. Improve and strengthen the role of the family, the education unit, society, and government to get involved and responsible in the development of the citizen potential of the country towards a developed nation, independent, and prosperous; and

3. Sort out the culture of the nation and filter the culture of other nations that are not following the cultural values and the noble character of the nation. 
In terms of character education of students, the implementation process needs to be done concretely, thus Martens (2004, p. 58) offers a strategy that is included in the multiple stages requiring the stimulated and continuous process, i.e. identify the principles of character, teach the principles of character, and provide opportunities to practice moral behaviour, which are described below: (Winarni, 2013)

1. Identify the values: the Identification of the value related to minimal particular moral values needed to be practised by students. In real community life, several values are embedded and growing deeprooted in a habit, belief, and symbols with the characteristics of them maybe different from one another. It is influenced by the culture that lives in the minds of the people. Therefore, in order to unify the differences in the understanding of a value, it needs to identify the values that are valid in a general and universal way which becomes the objective values at universities.

2. Teach the Values: Once the identification process is completed, it is then followed by a setting of the target value to be achieved, performing the in calculation or the teaching of moral values through the method of modelling, habituation, and intervention

3. The practice of the Value: After teaching the value, the next is to provide the social and emotional experience related to the character values. The success of the implementation of moral values in real life is because of the integration between concept and practice. Therefore, the learning model must be organized so that not only the theory but also provides a space and opportunity for students to apply the value.

\section{Intolerance and Radicalism of Religion}

Intolerance as explained by the Human Rights Organization of Council of Europe (Council of Europe) is the lack of respect for other practices and beliefs that differ from someones. (Dja'far, 2018, p. 30) In other words, intolerance is an attitude-an attitude that does not appreciate the different beliefs of others. (Mudzhar, 2011, p. 87)

Theoretically, the intolerance attitude can become one of the factors causing the religious conflict that resulted in the action of racism, sexism, fascism, ethnocentrism, antisemitism, xenophobia, imperialism, exploitation, or repression of religion. (Unesco, 1994, p. 20) Freedom of practice any religion or belief is one of the clumps in Human Rights (HR), which is formulated in the Universal Declaration of Human Rights (UDHR). (Rights, n.d., p. 74)

In its definition, religious intolerance according to the Wahid Institute(2011, p. 19) is an unwillingness to treat people of different religions equivalently which includes the negative bias of beliefs, affiliation or certain religious practices, both to the individual and the group. The negative bias at any time can be transformed into acts of intimidation or violence with the main motive waiver of the right of individuals and groups in performing their worship based on their belief and the waiver of the principle rights of the religious people. The other varieties can be propaganda, hate speech, or the other belief in the form of the action to propagate discriminatory ideologies.

The theme of freedom in practising religion and intolerance is essentially not new, nevertheless, it remains relevant to a pluralistic society context like Indonesia. The intolerant attitude in practising the religion is the revival seeds of the violent actions in the name of religion. The development of radicalism in Indonesia is a socio-historical fact in a multirace country, but if it is ignored, it can potentially be a threat to pluralism in Indonesia.

Radicalism is a belief or movement that urges a change or renewal of the social and political life in a violent way. In its development, radicalism has two dimensions: first, violence, that is the use of violence as a way to change the system that is already established. Second, active effort in making changes in the society radically. (Muhtarom, Karim, Choiron, Asmani, \& Hasyim, 2018, p. 18)

From the beginning we need to distinguish between radical, radicalism and radicalization, Hasyim Muzadi gives the limit 
of those three terms. A radical in his opinion is the people who think radical in the sense of thinking deeply and thoroughly (based on the word's meaning), it is considered fine and indeed the thinking process should be like that. While radicalism according to Muzadi is the radical in the belief or the ism, in other words, the radicals have been transformed into an ideology or school of thought. While radicalization that is understood by Muzadi is people being reactive when injustice occurs in the community. (Rokhmad, 2012)

The probability of thinking, behaving, and acting radically, having a radical ideology (radicalism) and then growing reactive to be radical (radicalization) is the beginning of a person to be the perpetrator of terror (terrorist) or a person who adheres the terror beliefs (terrorism). There is no terror without radicalism. On the contrary, the adherents of radicalism do not necessarily choose acts of violence (terror). However, there is a common language used between radicalism and terrorism, which is the language of the militants and the language of struggle. (Ali, 2013, p. 119)

Radicalism is not always related to terrorism, Syafii Maarif (2002) revealed that radicalism is more related to modelling the attitude and manner of disclosure of a person, while terrorism is more on the actions of a criminal for a particular purpose. However, it is not impossible if radicalism can culminate in terrorist actions. Radicalism ends on terrorism practice is assumed in the name of religion that is radicalization and interpretation as well as an understanding of religion that doesn't fit and seem hard, thus giving birth to the fundamentalists of Muslim who prefer the extreme action against other groups with the assumption that the truth belongs only to them.

Harahap (2017, p. 15) argued that generally there are ten marks and a hallmark of the radicals:

1. Being textual and rigid in understanding the sacred texts that led to the conclusion that jump (jumping to conclusion);

2. Extreme and fundamentalists. Extreme is an attitude that is always at odds with the mainstream or general course, while the fundamentalist is interpreted as a people who cling to the basics of something rigidly and textually;

3. Exclusive is glorified his own belief and practice while the view of other people is considered wrong, and;

4. Always eager to correct other people;

5. Justify the ways of violence and terror in correcting other people and in establishing as well as developing their belief and ideology;

6. Have fidelity across the country. In the sense that a radical act in a state can be controlled by the group in other countries;

7. The reconstruction of the enemies is often uncertain. By the reason of the difference in beliefs, principles, and views, friends from the same country can be considered as the enemy;

8. Because of the uncertain concession of the enemy, so they went all-out war (the war to death) against those perceived to be enemies;

9. Have a higher concern about the issues of the enforcement of the religious state, because it is considered managed to realize a world order that is more just and prosperous based on religion; and

10.Highly stress on tauhidiyyah hakimiyyah and condemning people who do not make the state as the basic law of the state and society.

\section{Deradicalization in Islamic Religious Universities}

Today, the most urgent agenda for all university leaders is not focusing on efforts to secure accreditation for the universities as the best or build networking with universities from abroad. However, it is optimized the internal campus activities, strengthen the identity as a nation of Indonesia. Every student must have a national identity that is strong, tough, and sturdy which is inherent with four consensuses of the nation, namely Pancasila, UUD 1945, Bhineka Tunggal Ika, and the Republic of Indonesia. (Idris, 2018, p. 57)

Since the variety of radicalism in several findings has been developed among university students, de-radicalization in higher education is a necessity. Based on the testimony of former Director-General of Islamic Education, Nur Syam who stated that in order to perform 
the de-radicalization, the best efforts could be by building a religious de-radicalization through educational institutions. (Fadlilah, 2019) However, it is important to realize that although proclaimed as a means of antidote to radical Islam, education and educational institutions are also potentially become a home base for the development and deployment of radicalism belief.

Based on the term, deradicalization has several definitions, including the methods and techniques used to undermine and reverse the process of radicalization as a whole, thereby reducing the potential risks for the people involved in terrorism. (Alimi, 2018, p. 157) In a broad sense, de-radicalization can be interpreted as an attempt to neutralize the radical ideology through a multi and interdisciplinary (religious, social, cultural, etc.) for those who are influenced by radical or pro-violence belief. (Amirsyah, 2012, pp. 3536)

Based on those insights, in the middle of the variety of religious ideology euphoria, the preventive efforts in addressing the spread of radicalism in the PTKI are by having a deradicalization of the religious program through the moderation of practising the religion that offers a moderate religious pattern. Religious moderation is expected to foster social values of the religious community, both on the local, regional, national, as well as global scale, to dilute the tension of different potential parties that cause tension and conflict. (Wijaya \& dkk, 2020, pp. 131-132)

The Ministry of Religious Affairs of the Republic of Indonesia through the Directorate General of Islamic Education had issued a Circular Letter of the Director-General of Islamic Education, Number B3663.1/Dj.I/BA.02/10/2019 on 29 October 2019 about the Circular House of Religion Moderation. The circular letter is part of committed policy implementation to make the moderation of religious practice as part of the foundation of thinking, acting, and the formulation of policies and programs at all stakeholders of the Ministry of Religious Affairs, including PTKI. ("Semua Kampus PTKI Mendirikan Rumah Moderasi Beragama," 2019)

Operationally, the moderation of religion can be characterized by the religious attitude under the basic principles, namely: first, receive the form of the state of the godhead, rejecting the form of a secular state and theocracy, as well as consider the Pancasila as the basis of the state and the final nation. Second, be tolerant to accept the presence of a plurality and diversity of religions and beliefs in Indonesia. Third, choose the approach of dialogue and peaceful methods in resolving conflicts and differences of opinion and avoid any violent acts. (Wahab, 2019, p.xi)

\section{RESEARCH METHOD}

Based on the research objectives needed to be achieved, that is to describe the patterns of students ' character development through students activities in Islamic Religious Universities in West Sulawesi in anticipating the spread of intolerant belief, this study employs descriptive research. Leaning on the source of the data using analysis based on facts and reality found in the field, this research is field research, while based on the type of data and the research process, this study is qualitative research. It can be concluded that the research method used in this research is descriptive-qualitative research with the main data source being field research.

This study was conducted in 4 (four) Islamic Religious Universities in West Sulawesi located in 3 (three) regencies, namely: Polewali Mandar, Majene, and Mamuju. The distribution of the regencies are then described in the following table:

Table. 1: Location of the Research

\begin{tabular}{|c|c|}
\hline Name of PTKI & Location \\
\hline $\begin{array}{l}\text { Sekolah Tinggi Agama } \\
\text { Islam Negeri (STAIN) } \\
\text { Majene }\end{array}$ & $\begin{array}{l}\text { Jl. Balai Latihan Kerja No. } 15 \\
\text { Passarang Majene Regency, } \\
\text { West Sulawesi }\end{array}$ \\
\hline $\begin{array}{l}\text { Institut Agama Islam (IAI) } \\
\text { Darul Da'wah Wal Irsyad } \\
\text { Polewali Mandar }\end{array}$ & $\begin{array}{l}\text { J1. Gatot Subroto No. 61, } \\
\text { Madatte, Polewali Mandar } \\
\text { Regency, West Sulawesi }\end{array}$ \\
\hline $\begin{array}{lrr}\text { Sekolah } & \text { Tinggi } & \text { Agama } \\
\text { Islam } & \text { (STAI) } & \text { Darul } \\
\text { Da'wah Wal Irsyad Majene }\end{array}$ & $\begin{array}{l}\text { Jl. Andi Pangerang Pettarani } \\
\text { No. 24, Majene Regency, } \\
\text { West Sulawesi }\end{array}$ \\
\hline $\begin{array}{l}\text { Sekolah Tinggi Agama } \\
\text { Islam (STAI) Al-Azhary } \\
\text { Mamuju }\end{array}$ & $\begin{array}{l}\text { J1. Gatot Subroto No. 29, } \\
\text { Simbuang, Mamuju Regency, } \\
\text { Sulawesi Barat }\end{array}$ \\
\hline
\end{tabular}

The source of the data used in this research is divided into two, namely primary data sources and secondary data sources. The source of primary data was obtained based on the results of in-depth interviews with key 
informants who are considered competent and comprehended in providing information related to the implementation of student activities.

Table. 2: The Research Informants

\begin{tabular}{lll}
\hline \hline Name & Position & Institution \\
\hline \hline $\begin{array}{l}\text { Dr. Anwar Sadat, } \\
\text { M.Ag }\end{array}$ & $\begin{array}{l}\text { Vice-Chairman } \\
\text { III }\end{array}$ & STAIN Majene \\
\hline $\begin{array}{l}\text { Dr. Ahm } \\
\text { Muaffaq, M.Pd }\end{array}$ & $\begin{array}{l}\text { The head of the } \\
\text { P2M }\end{array}$ & STAIN Majene \\
\hline $\begin{array}{l}\text { Drs. H. Abdullah, } \\
\text { M.Si }\end{array}$ & Chairman & STAI DDI \\
\hline $\begin{array}{l}\text { Drs. H. Mansur, } \\
\text { M.Pd.I }\end{array}$ & Vice-Chairman & STAI DDI \\
$\begin{array}{l}\text { Dr. Anwar } \\
\text { Sewang, M.Ag }\end{array}$ & Rector & IAI DDI \\
$\begin{array}{l}\text { Dr. Basri } \\
\text { Mahmud, M.Thi }\end{array}$ & $\begin{array}{l}\text { Head of } \\
\text { Language }\end{array}$ & IAI DDI \\
& $\begin{array}{l}\text { Development } \\
\text { Centre }\end{array}$ \\
\hline $\begin{array}{l}\text { Syamsul S.Pd.I., } \\
\text { M.A }\end{array}$ & Chairman & STAI Al-Azhary \\
\hline Hasbar, S.Pd.I., & Head of & STAI Al-Azhary \\
M.Pd.I & Department & \\
\hline \hline
\end{tabular}

Secondary data sources are obtained in the form of existing documents and the research results as well as the direct findings in the field. The data can also be obtained from some references such as books, the internet, printed and electronic media which are related to the theme of this research.

\section{DISCUSSION}

\section{The Pattern of Students' Character Development at PTKI in West Sulawesi}

In this section, the author tried to outline the shape of the religious moderation practice as an attempt to anticipate the spread of intolerant ideologies and radicalism that is reflected in the academic and student activities at four PTKI which became the locus of this research. The description of students' character development patterns in this research is based on the synergogy concept of which technically focused on the application in the form of training, consulting, mentoring, managing, and leading.

\section{Training Pattern}

STAIN Majene develop a curriculum based on the religious national standard of PTKI which is then implemented in a learning process based on the strengthening of Islamic studies. Courses arranged in STAIN Majene are integrated with the Islamic sciences by adopting the pillars of Islam, nationality, and the local culture which contains the values of character education. By that, the adoption of Islamic studies in each of the courses taught is very important in the student's character building.

As the efforts of mainstreaming approach of the intolerant attitude and antiradicalism, according to the Head of the Quality Assurance Center Dr Ahmad Muaffak, M.Pd. STAIN Majene have been applying the integrated curriculum pattern that is the unification of all of the subjects in a systematic integral way by incorporating the material of anti-radicalism in the content of the curriculum. For example, there is an antiradicalism value contained in the subdiscussion in the institution subject, this is under the classification of groups of subjects listed in the Educational Guidelines of STAIN Majene(2019, p. 18) that explains the institution subject is a Personality Development subject (MPK) and Living in a Society (MBB) subject that could realize a religious and humanist student.

In addition to the alignment of antiradicalism based curriculum, training in the form of the reasoning and expertise in the academic forum by bringing in speakers/experts outside the learning process in the classroom is also applied as the efforts to grow and strengthen the nationalism values as well as an understanding the negative impact caused by the practice of violence in religion.

The implementation is in the form of seminars and studium generale themed strengthening the values of character education through Islamic studies. Dr. Anwar Sadat, M. $\mathrm{Ag}$ as the vice-chairman of the student affairs explained that the concept of nationalism is the mandatory content in the Introduction of Academic Culture and Student Affairs (PBAK) activity.

Table. 3: Reasoning and Expertise Related with AntiRadicalism in STAIN Majene

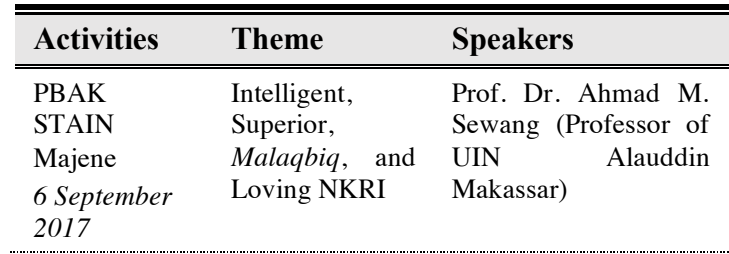




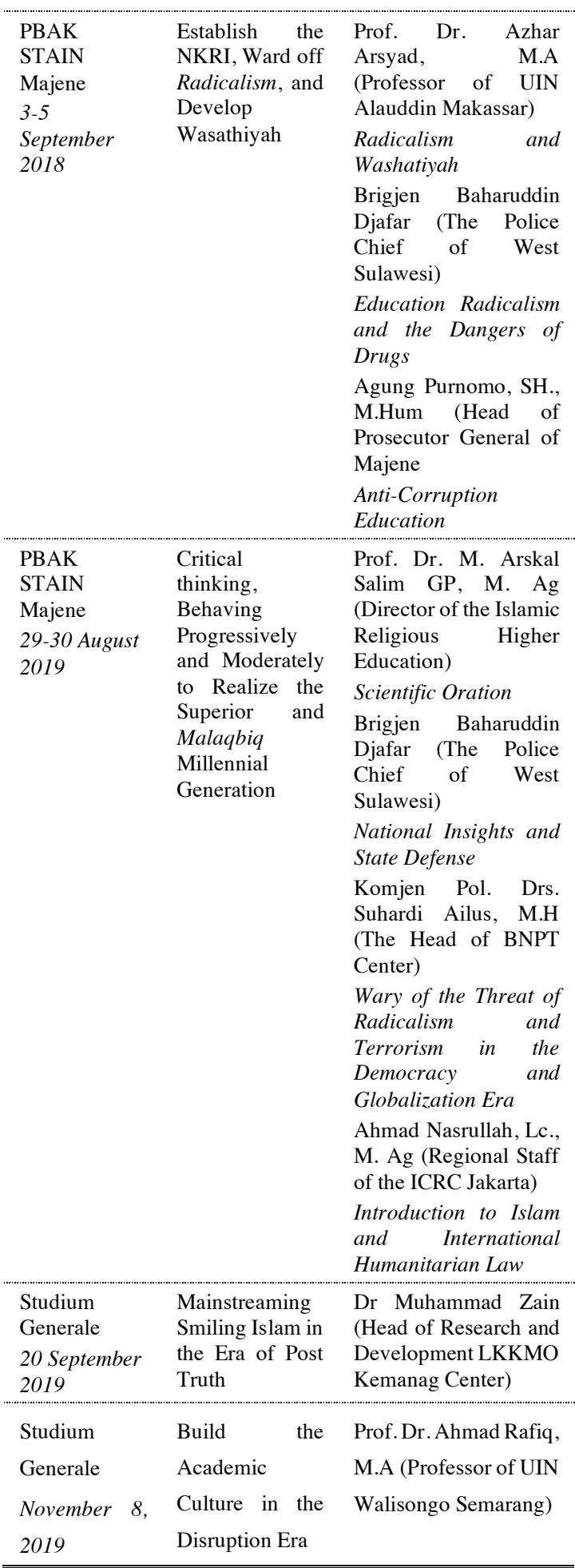

In addition to building the concept of nationalism, to increase the student's spirituality, the closing segment in the PBAK activity was performed by doing Great Dzikr led by Annangguru KH. Dr. Ilham Saleh as the Great Murshid of Tariqah Qadiriyyah with the hope that in their early career, the new students are always in the pleasure of God.

STAI DDI Majene adheres to the pattern of an integrated curriculum that combines general education with religious education, which is incorporated in a single unit with a focus on Darud Da'wah Wal Irsyad (DDI) Trilogy, namely faith, science, and righteous deeds.

Drs. H. Abdullah, M.Si as the Chairman of the STAI DDI Majene explained that the management of religious education and higher education under the auspices of the DDI should reflect the goals of the DDI organization, because the truth is, every level of education is an extension of the hand of the DDI organization.

In the DDI Association Statute, Chapter II, Article 6 stated that "the Organization is founded to maintain the individual Muslim, faithful and devoted, Akhlakul Karima who served and practice of fisabilillah effort, enforce and uphold the religion of Islam, for the sake of the realization of a prosperous society blessed by Allah the Almighty God". (Arsyad, Jihad, Rasyid, Hasbuddin, \& Ab, 2003, p. 55)

Starting from that idea, Abdullah added that in the field of education, the program initiated by DDI was oriented on:

a. The integration between education, religion science and general science, so there is no dichotomy of science that make the gap between the two;

b. Education is conducted towards the creation of tolerant attitudes and behaviour, sincere feeling in various things and fields, especially tolerant toward the differences of opinion in understanding/interpreting the teachings of Islam, without letting go of opinion and way of thinking, which he believed;

c. The education developed by DDI is directed toward self-reliance attitudes.

In connection with efforts to prevent the entry of radicalism belief, besides the national compulsory subjects, STAI DDI assign subjects related to DDI's value as a compulsory subject programmed by any of the new students, transfer students, and change students. Through education of DDI's values, it is expected to be a shield against faceted social pathology phenomenon emerged including radicalism. Therefore, an important agenda developed in the education of DDI's value is: (Arsyad et al., 2003, p. vii) 
a. The development of personal life, including tend to be in the truth, subject to the law, honesty, courtesy, and helping each other;

b. The development of family values, including a sense of responsibility, support, protection of the moral and togetherness;

c. The development of social ties, such as tolerance, social justice, respect for the rights of the individual;

d. The development of democratic values, including justice, obeying the law, and freedom of speech.

As a form of the value investment at an early stage about DDI's values, in the PBAK activities, Abdullah who is usually delivered the subject explained that the material of DDI's values is a mandatory subject which is not only about the social religious issues and contemporary issues, but also the concept of nationalism.

Table. 4: Content and Subthemes of DDI's Values

\begin{tabular}{ll}
\hline \hline Materia & Sub-theme \\
\hline \hline DDI's & The vision and Mission of the DDI \\
Values & - Education \\
& - Da'wah \\
& - Social Enterprises \\
& DDI's Life Guidelines \\
& - Mahdah A Guide To Life \\
& - The Foundation and Source of Life \\
& Guidelines \\
& - DDI's Life Guidelines \\
& DDI Guidelines To Contemporary Issues \\
& - Views On Gender \\
& - Views On human Rights \\
& - The concept of Democracy and Civil \\
& Society \\
\hline \hline
\end{tabular}

During the students coaching conducted by the STAI Al-Azhary, Syamsul, S.Pd.I., M.A as the Chairman explained that the strategy is implemented through the method of preparation of competency-based curriculum that the content based on character education, which is intended to be in line with the vision of the institution that oriented to the achievement of the intellectual and the spiritual equations.

Further, he explained that in the practice, the approach used is divided in the form of structural and non-structural, which is structurally through the process of formal learning in the classroom, while non-structural is carried out through the scientific activities which are accompanied directly by the lecturer.

As a university under the auspices of the Organization of DDI, IAI DDI Polman apply the same thing of the STAI DDI Majene. In line with the statement of Abdullah, the chairman of the STAI DDI Majene, Dr. H. Anwar Sewang, M. Ag, which now served as the Rector, added that the DDI's education has characteristics, namely through the provision of religious studies subjects and the DDI's values which are integrated comprehensively in the learning curriculum, both those taught in a formal class, recitation of the book in Mahad al-jamiah, as well as programs and other activities held on campus.

Anwar Sewang explained that in addition to the DDI trilogy, the education organized by the organizational unit of DDI should be oriented on the understanding, appreciation, and practice of the teachings of Islam Ahlussunnah Wal Jamaah.

Due to the rise of radicalism, further, Anwar Sewang also explained that the IAI DDI Polman is committed to still and always giving a moral touch to the nation and state life. It is intended that the IAI DDI is able to instil the skills of moral and social so that students are able to contribute their thoughts and solutions to social problems, such as tolerance, pluralism, da'wah inclusive, etc.

Every year, IAI DDI carry out activities in the form of seminars and studium generale under the theme of student character education, such as:

Table. 5: Reasoning and Science Related AntiRadicalism in the IAI DDI Polman

\begin{tabular}{|c|c|c|}
\hline Activities & Theme & Speakers \\
\hline $\begin{array}{l}\text { National } \\
\text { Dialogue } \\
19 \text { February } \\
2016\end{array}$ & $\begin{array}{l}\text { Indonesia } \\
\text { Without } \\
\text { Caliphate } \\
\text { Radicalism } \\
\text { Religion }\end{array}$ & $\begin{array}{lr}\text { KH. } & \text { Muhammad } \\
\text { Idrus } & \text { Ramli } \\
\text { (Missionary } & \text { of } \\
\text { PWNU Jawa } & \text { Timur) }\end{array}$ \\
\hline $\begin{array}{l}\text { Studium } \\
\text { Generale and } \\
\text { Tausiyah of } \\
\text { Nationality } \\
5 \text { October } \\
2017\end{array}$ & $\begin{array}{l}\text { Counteract the } \\
\text { Radicalism } \\
\text { Belief }\end{array}$ & $\begin{array}{l}\text { Prof. Dr. KH. Said } \\
\text { Aqil Siraj, MA } \\
\text { (Chairman of the } \\
N U)\end{array}$ \\
\hline $\begin{array}{l}\text { Religious } \\
\text { Seminar } \\
24 \text { May } 2017\end{array}$ & $\begin{array}{l}\text { The Thought of } \\
\text { Aswaja in Facing } \\
\text { the Challenges of } \\
\text { Religious } \\
\text { Radicalism }\end{array}$ & $\begin{array}{l}\text { Prof. Dr. KH. Andi } \\
\text { Syamsul Bahri, M.A } \\
\text { (The chairman of the } \\
\text { PB-DDI) }\end{array}$ \\
\hline
\end{tabular}




\begin{tabular}{|c|c|c|}
\hline $\begin{array}{l}\text { PBAK IAI } \\
\text { DDI Polman } \\
6 \text { September } \\
2017\end{array}$ & $\begin{array}{l}\text { Countermeasures } \\
\text { of Radicalism, } \\
\text { Terrorism, } \\
\text { Corruption, and } \\
\text { Plagiarism }\end{array}$ & $\begin{array}{l}\text { AKBP Muhammad } \\
\text { Rivai }\end{array}$ \\
\hline $\begin{array}{l}\text { PBAK IAI } \\
\text { DDI Polman } \\
25-28 \text { August } \\
2018\end{array}$ & $\begin{array}{l}\text { Creating A } \\
\text { Creative Person, } \\
\text { Discipline, and } \\
\text { Noble Character }\end{array}$ & $\begin{array}{l}\text { Hari Purnomo S. } \\
\text { Hub Int M.Han } \\
\text { (Commander 1402) }\end{array}$ \\
\hline $\begin{array}{l}\text { Scientific } \\
\text { Oration on } \\
\text { First Lecture } \\
5 \text { January } \\
2019\end{array}$ & $\begin{array}{l}\text { The } \\
\text { Implementation } \\
\text { of Islamic Values } \\
\text { Ahlussunnah } \\
\text { wal-Jama'ah As } \\
\text { A Form of } \\
\text { Rahmatan Lil } \\
\text { Alamin }\end{array}$ & $\begin{array}{l}\text { Prof. Dr. Phil. } \\
\text { Kamaruddin Amin, } \\
\text { M.A (The General } \\
\text { Director of Higher } \\
\text { Education) }\end{array}$ \\
\hline $\begin{array}{l}\text { Studium } \\
\text { Generale } \\
25 \quad \text { February } \\
2019\end{array}$ & $\begin{array}{l}\text { The Challenges } \\
\text { of Literacy and } \\
\text { Moderation in } \\
\text { Practicing } \\
\text { Religion }\end{array}$ & $\begin{array}{l}\text { Dr. Muhammad } \\
\text { Zain, M. Ag (Head } \\
\text { of the Center for } \\
\text { Research, } \\
\text { Development, } \\
\text { Education and } \\
\text { Training Religious } \\
\text { Affairs of Indonesia) }\end{array}$ \\
\hline $\begin{array}{l}\text { Public Lecture } \\
\text { in } 2017\end{array}$ & $\begin{array}{l}\text { Build Awareness } \\
\text { of the Country's } \\
\text { Defense in the } \\
\text { Life of Nation } \\
\text { and State }\end{array}$ & $\begin{array}{l}\text { Commissioner } \\
\text { Hanny }\end{array}$ \\
\hline
\end{tabular}

\section{Consulting Pattern}

To shape the character of students, the role of the academic advisor or supervisor (PA) is needed. Therefore, every year STAIN Majene points and assigns the faculty to be academic advisors.

In order to increase the role of academic advisors, STAIN Majene carry out a Workshop on the Preparation of Academic Advisors Guidelines on August 1, 2019.

One of the roles and functions of academic advisor (PA) contained in the Academic Advisors Guidebook of STAIN Majene (2019, p. 7)is to be: "Model, which is to provide exemplary as a professional educator and under the Pancasila morality".

From the explanations, STAIN Majene clearly and do instil nationalism on the students, where the lecturers are required to display the figure of the statesman with Pancasila values so they become an exemplary model for the students. Therefore, in the descriptions, the faculty that acts as the academic advisors are assigned to guide students in developing his personality under the philosophy of the Indonesian nation (based on Pancasila). (Pusat Penjaminan Mutu, 2019, p. 9)
In the Academic Guidebook of STAI DDI Majene (2017), the role of the Academic Advisor is dominantly filled by guidance regarding student academic, however, guidance to DDI's values remains a priority. It is expected that the attitude and actions of the student always reflect the character of DDI citizens.

Abdullah added that the internalization of DDI's values through academic guidance is expected to shape the identity that can survive amid the competition of the various ideologies that are not following the teachings and beliefs embraced by DDI including intolerant and radicalism.

Syamsul argued that in accordance with the vision of STAI Al-Azhary, we do not only increase the intellectual quotation of students, instead, it works hard so that they also master spiritual intelligence, one of them is through academic guidance.

The Academic Guidelines of STAI AlAzhary (2016)at least formulate 8 roles of the academic advisor. The formulation refers to the vision of the campus that rests on two main orientations, namely intellectual values and spiritual values. One of the Academic Advisor roles which lead to the development of spiritual values is the role explained as "introducing the value of life".

In relation to the Mamuju people where the STAI Al-Azhary is located, the life of the community that multi-religion and multiethnic potentially causing the conflict. Related to that condition, the moral value of and ethics is emphasized by the academic advisor to their students is the attitude of tolerance and appreciation of the difference. Thus, STAI AlAzhary has played an active role in closing one of the doors as the entrance of radicalism belief that is the attitude of intolerant and exclusivism.

Similar to the first 3 PTKI, IAI DDI also appoints academic advisors from lecturers who assign to direct and guide the students. In summary, the responsibility of academic advisors consists of 2 (two) namely main tasks and special tasks. In the context of combating radicalism, it is set forth clearly in the Academic Guidebook of IAI DDI (2016)as the part of the special job description for academic advisors, which is "Instill character education, the dangers radicalism, and the impact of 
religious moderation in each of the guiding activities".

The items which set the special task of the academic advisor is a form of implementation of habituation religious humanist attitude, tolerant, and inclusive in every event experienced by the student following the teachings espoused by the IAI DDI namely the ahlussunnah wal jamaah.

\section{Mentoring Pattern}

The mentoring program conducted by the STAIN Majene is Malaqbiq Character Building Program (MCBP). The program is an activity the enlightenment synergies between Islamic values as well as intellectual abilities that are multi-disciplinary, emotional, spiritual, cultural, and social. (Pusat Panjaminan Mutu, 2019, p. 6)

According to Ahmad Muaffak, MCBP is a flagship program that is part of the implementation of deradicalisation programmes which are offered by the STAIN Majene as well as the efforts to preserve the local wisdom culture of Mandarese which is the glorious legacy of the ancestors derived from the practice of religion assimilated with a culture that was assumed to have managed to realize a harmonious relationship in the life of the state.

In the practice, this program is mandatory for all new students, including transfer and change students. MCBP is implemented by 3 (three) divisions, namely: the Mastery of a Foreign Language, Learning to Read and Write the Qur'an, the Strengthening of Local Wisdom, as well as the Study of the Source Book.

In order to internalize the values of the DDI's which are oriented on ideology and ahlussunnah wal jama'ah belief, the mentoring pattern conducted by the STAI DDI is through a program of Foreign language and Tahfidz Qur'an. Abdullah explained that through this program the students practice nurturing a tolerant attitude, in language learning, we use the method of muhadatsah while in the tahfidz program using the method of sima'an. In muhadatsah, students face each other while having the dialogue in Arabic or English, they strive to understand the speech of the interlocutor, wait for their turn to speak, accept each other's faults if there are errors and mutual correcting. Meanwhile, in sima'an, they sit face to face, one reciting their memorized Qur'an and the other heard while correcting if there is an error, once completed they will change roles.

By using these two methods, the students not only learn but also actualize a directly tolerant attitude that is reflected from the behaviour of mutual respect, mutual understanding, being patient waiting for their turn, as well as correcting other mistakes wisely and politely.

Character education in STAI Al-Azhary Mamuju leads to an increase in intellectual and spiritual values. Thus, the coaching program that is done in the form of mentoring is the Student Boarding School Program.

In practice, Syamsul explained that the program is intended for students who want to study while mole in the dorm that we have provided. Meanwhile, the activities which are carried out in this program are Tahsin and Tahfidz Qur'an, the Study of the Arabic Language, Fiqh, Hadith and Tafsir.

To guarantee the well-balanced of intellectual and spiritual development, in addition to these activities, the students carry out the prayer in congregation, exercise providing preach in turns, as well as optimize the acts of complementary worship such as the Monday-Thursday fasting, Ayyamul Beidfasting, 'Ashura fasting, 'Arafah fasting, Duha prayer and Tahajjud, etc.

The Student Boarding School Program according to Syamsul was effective in shaping the student characters, their existence in the dormitory are filled with many dynamic activities with religious nuanced that leave no room for any violent behaviour and actions, but instead, they learn the meaning of togetherness, discipline, tolerance and mutual respect.

Students' character development in particular has become the focus of attention of the IAI DDI Polman. Thus, IAI DDI offers excellent programs related to the development of character and science students through A Study Centre for the Development of Foreign Language and Ma'had al-jami'ah.

Specifically, Dr. Basri Mahmud, Lc., M.Th.I as the head of the Study Center for Language Development in IAI DDI Polman explained that Foreign language skills 
potentially make the students have the immune to anti-radicalism because by having these capabilities, they can learn religious knowledge through the study of Islamic sources in Arabic as well as supporting information of the journal and articles which are in English so that they can filter out the wrong belief including radicalism.

Moreover, Basri added that as the continuation of the program, there are a Takhassus Qiraatul Pole and Tahfidz al-Quran Program which have now turned into Ma'had al-jami'ah. In its activities, the program offers several book studies which allegedly can even become a shield against radicalism, some of the studies are:

Table. 6: Islamic Book Studies of Ma'had Al-Jamiah IAI DDI Polman

\begin{tabular}{|c|c|c|}
\hline Book & Author & Indicator \\
\hline $\begin{array}{l}\text { Tazkiyah al- } \\
\text { Nufus }\end{array}$ & $\begin{array}{l}\text { Syaikh } \\
\text { Ahmad } \\
\text { Farid }\end{array}$ & $\begin{array}{l}\text { The self-purification as } \\
\text { well as the formation of } \\
\text { the religious Muslim } \\
\text { characters }\end{array}$ \\
\hline \multirow{2}{*}{$\begin{array}{l}\text { Bidayah al- } \\
\text { Mujtahid wa } \\
\text { Nihayah al- } \\
\text { Muqtashid }\end{array}$} & \multirow[t]{2}{*}{$\begin{array}{l}\text { Syaikh } \\
\text { Rusyd }\end{array}$} & $\begin{array}{l}\text { Developing the analogy } \\
\text { thinking ability in } \\
\text { summing up the law }\end{array}$ \\
\hline & & $\begin{array}{l}\text { Forming Muslim } \\
\text { characters which are not } \\
\text { fanatics as well as } \\
\text { accepting the existence of } \\
\text { a plurality of opinions }\end{array}$ \\
\hline
\end{tabular}

\section{Managing Pattern}

Student activity is always directed on the study of nationalism concepts so that the students understand the importance of togetherness in multicultural life. In order to develop creativity, reasoning, leadership, and student character, STAIN Majene conducted direct coaching through Student Organizations (ORMAWA), namely: Student Senate (SEMA), Student Council (DEMA), Student Association of the Department/Study Program (HMJ/HM-PS), as well as the Student Activity Unit (UKM) in the field of art (Sipamandaq), in the field of sports, scouts (Racana Imam Lepeo and Andi Depu), as well as other UKM which became the characteristic of the study program.

Anwar Sadat explained that through the student organization, students are expected to understand the importance of unity, solidarity, democracy, and tolerance so that the actions that lead to a violent, intolerant and belittling the dignity of the other party, considered as something that deviates from the value of the character and morals of the nation.

In this context, the Student PocketBook (2019, p. 43)has formulated that the Student Organization as a medium and a means of academic development, noble, the increase of piety, and coaching the integrity of the society through co-curricular and extracurricular activities.

In the implementation, student organizations participate and contribute to the development of character with the leading party, both at the universities, department, and study program. The participation of students organization in the activities and committees on campus is the process of habituation for students, that will form independent character and has the leadership skills as well as become an exemplary model for other students.

On the other hand, there are several forms of activities that were successfully carried out by student organizations in order to mainstream the moderation of religion, such as the ones documented in the following table:

Table. 7: Student Organization Activities of STAIN Majene

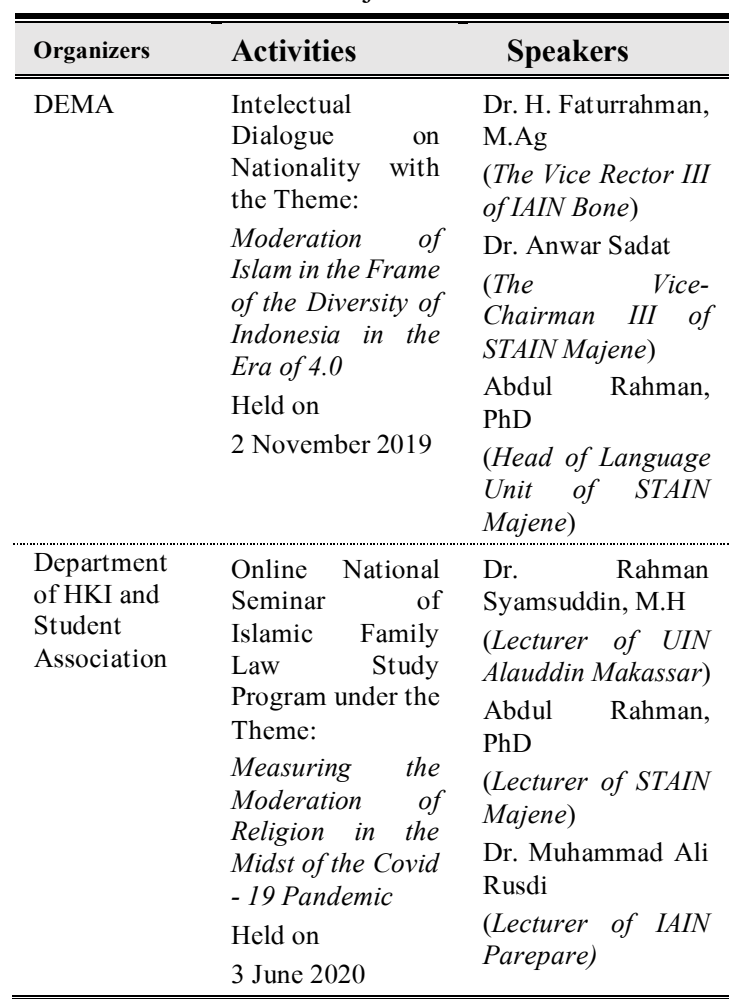

The formation of the character of the students in the campus environment is not only done in the process of formal learning in the classroom but can be done through student organizations. Abdullah said that the Book of 
the Set of Rules of the DDI Organization explained that the way of character development through the student organization is an important part that must be implemented by each campus under the auspices of the DDI.

It is intended to form the soul of leadership, the development of interests and talents, as well as to produce a tough cadre of DDI. (Himpunan Peraturan Organisasi Darud Dakwah Wal-Irsyad, 2017, p. 89) Thus, to comply with the rules, the STAI DDI forms a Student Organization that manifest in the Student Executive Board (BEM), and the Student Activity Unit (UKM). Some of the Student Activity Unit in STAI DDI are Internal Preacher Unit (Lembaga Dakwah Kampus/UKM), Scout and Student Cooperation Unit (Koperasi Mahasiswa/KOPMA).

Furthermore, Abdullah interprets the meaning of "tough" through the understanding of the DDI's values where a cadre of DDI could respond to the issue of humanitarian, religion, and nationality. Therefore, student development through the activities of the student organization must be oriented to the achievement of the DDI trilogy. No wonder if then found a variety of student's organization activities which leads to the formation of the identity of the Indonesian nation and the identity of the DDI's member.

Table. 8: Student's Organization Activities of STAI DDI

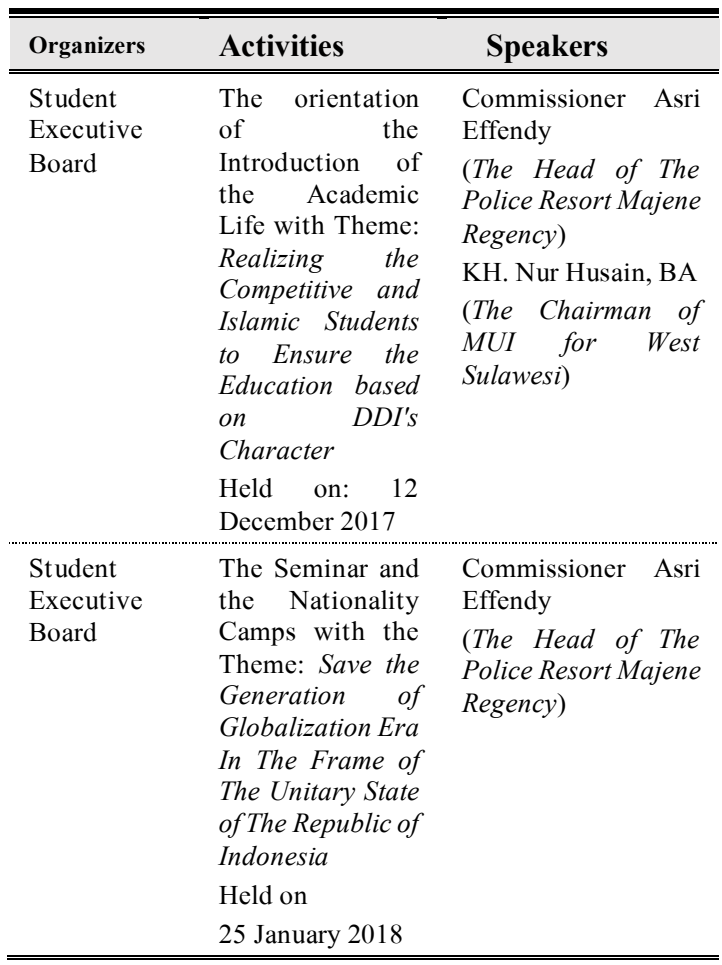

In the formation of character, Syamsul S.Pd.I., M.A as the chairman of STAI AlAzhary explained that all parties should be involved to take on this role, not to mention the students themselves through the Student Organizations that are facilitated by the campus. All activities organized by the student organization must be with the permission of the campus, to synergize with the vision of the campus. The activity is directed at the optimization of the academic based and educational program. Some of the Internal Organizations provided are the Student Executive Board (BEM), Student Association of the Study Program (HMP), Student Regimen (MENWA), the Indonesian Red Cross (PMI), Scouts, Studio Art of Sapota, Sports, and Martial Arts.

In its application, student organizations also take part in the socialization of understanding of Islam that is tolerant and inclusive as well as the strengthening of the concept of nationalism through several activities, including:

Table. 9: Activities of Student Organization of STAI AlAzhary

\begin{tabular}{|c|c|c|}
\hline Organizers & Activities & Speakers \\
\hline $\begin{array}{l}\text { Student } \\
\text { Executive } \\
\text { Board }\end{array}$ & $\begin{array}{l}\text { Student Leadership } \\
\text { Training. Theme: } \\
\text { Realizing the } \\
\text { Students with } \\
\text { Leadership and } \\
\text { Intellectual, } \\
\text { Spiritual, Socialist } \\
\text { and Humanist } \\
\text { Vision. } \\
\text { Held on } \\
8 \text { March } 2012\end{array}$ & - \\
\hline $\begin{array}{l}\text { BEM with } \\
\text { LDK }\end{array}$ & $\begin{array}{l}\text { Religious } \\
\text { workshops, Theme: } \\
\text { Learning Design for } \\
\text { The Development of } \\
\text { Islamic Understan- } \\
\text { ding that is } \\
\text { Rahmatan } \\
\text { 'Alamin Lil } \\
\text { Held on } 21 \text { July } \\
2018\end{array}$ & $\begin{array}{l}\text { Police Brigadier } \\
\text { General Drs. } \\
\text { Baharuddin } \\
\text { Djafar, M. Si (The } \\
\text { Police Chief of } \\
\text { West Sulawesi) } \\
\text { Dr. H. Husain Al- } \\
\text { Fulmasi (Head of } \\
\text { Department of } \\
\text { Economic Law } \\
\text { Sharia STAIN } \\
\text { Majene) }\end{array}$ \\
\hline $\begin{array}{l}\text { UKM Studio } \\
\text { Art of } \\
\text { Sapota at } \\
\text { STAI Al- } \\
\text { Azhary }\end{array}$ & $\begin{array}{l}\text { Discussion of } \\
\text { Nationality in } \\
\text { Commemoration of } \\
91 \text { st Youth Pledge } \\
\text { Day, Theme: } \\
\text { Determination of } \\
\text { The Nation's } \\
\text { Generation } \\
\text { Held on 3/11/2019 }\end{array}$ & $\begin{array}{l}\text { Dr. Mahyuddin } \\
\text { Abdullah, M.Ag } \\
\text { (The Senator of } \\
\text { Mamuju Regency) }\end{array}$ \\
\hline
\end{tabular}


To ensure the sustainability of the coaching and mentoring of student activities, IAI DDI prepares a place in the form of Internal Student Organizations on the campus. For development that oriented on governance and managerial leadership, the implementation is done through the Student Executive Board (BEM), the Executive Board of the Student (DEMA), and Student' Organization at The Department Level (HMJ), while the Student Activity Unit (UKM) intended for the development of interests, talents and passions of students, including Art Activities and Sports, Student Leadership Training, Coaching and Development Study Group, Boy Scouts, the KMD and KML Activities, Nature Lover Student, etc.

As a place to foster brotherhood, a student organization is contributing to realizing the goal of IAI DDI in developing insights, improving skills, as well as shaping the character of students through activities such as training, seminars, and discussions. Some of the activities of the student organization are:

Table. 10: Student Organization Activities of IAI DDI

\begin{tabular}{|c|c|c|}
\hline Organizers & Activities & Speakers \\
\hline $\begin{array}{l}\text { Student } \\
\text { Executive } \\
\text { Board }\end{array}$ & $\begin{array}{l}\text { A Cadre Basic } \\
\text { Training for Student } \\
\text { Association of DDI } \\
\text { Polewali Mandar } \\
\text { with the Theme: } \\
\text { Build the Capacity of } \\
\text { Militancy Cadre } \\
\text { Based on Moral } \\
\text { Movement and } \\
\text { Commitment in the } \\
\text { Frame } \\
\text { Ahlussunnah } \\
\text { Jama'ah } \\
\text { Held in } 2016\end{array}$ & $\begin{array}{l}\text { Prof. Dr. Samsul } \\
\text { Bahri A Galigo, } \\
\text { Ma (Head of PB- } \\
D D I)\end{array}$ \\
\hline $\begin{array}{l}\text { Student } \\
\text { Executive } \\
\text { Board }\end{array}$ & $\begin{array}{l}\text { The National } \\
\text { Dialogue with the } \\
\text { Theme: } \\
\text { The implementation } \\
\text { of Pancasila Values } \\
\text { in Public Life of the } \\
\text { Nation and State } \\
\text { Held in } 2017\end{array}$ & $\begin{array}{l}\text { Commissioner } \\
\text { Hanny (Chief of } \\
\text { Polman Police) }\end{array}$ \\
\hline $\begin{array}{l}\text { Student } \\
\text { Executive } \\
\text { Board }\end{array}$ & $\begin{array}{l}\text { Student Discussion } \\
\text { of IAI DDI Polman } \\
\text { and the Public with } \\
\text { the Theme: } \\
\text { The ideology of } \\
\text { Pancasila As the } \\
\text { Adhesive of the } \\
\text { Nation in the General } \\
\text { Election } \\
\text { Held in } 2018\end{array}$ & $\begin{array}{l}\text { Munawir Arifin } \\
(\text { KPU } \\
\text { commissioner of } \\
\text { Polman })\end{array}$ \\
\hline
\end{tabular}

\begin{tabular}{|c|c|c|}
\hline \multirow{8}{*}{$\begin{array}{l}\text { HMJ KPI } \\
\text { with the } \\
\text { Department } \\
\text { of Youth, } \\
\text { Sports, and } \\
\text { Tourism of } \\
\text { Polman } \\
\text { Regency }\end{array}$} & Management training & \multirow{8}{*}{$\begin{array}{l}\text { Mustari Mula } \\
\text { (Acting Officer } \\
\text { Department of } \\
\text { Youth, Sports, } \\
\text { and Tourism of } \\
\text { Polman) }\end{array}$} \\
\hline & $\begin{array}{l}\text { of Youth and } \\
\text { Improvement of }\end{array}$ & \\
\hline & Nation Character & \\
\hline & Building with the & \\
\hline & Theme: & \\
\hline & We Improve The & \\
\hline & $\begin{array}{l}\text { National Character } \\
\text { of the Youth Polman }\end{array}$ & \\
\hline & $\begin{array}{l}\text { Held on } 29 \text { December } \\
2018\end{array}$ & \\
\hline \multirow[t]{5}{*}{ HMJ KPI } & $\begin{array}{l}\text { Basic Training of } \\
\text { Da'wah }\end{array}$ & \multirow[t]{5}{*}{$\begin{array}{l}\text { Bustamin B, S.T., } \\
\text { M.Pd }\end{array}$} \\
\hline & $\begin{array}{l}\text { Communication with } \\
\text { Theme: }\end{array}$ & \\
\hline & Building & \\
\hline & $\begin{array}{l}\text { Character Values of } \\
\text { Local Wisdom }\end{array}$ & \\
\hline & Held in 2019 & \\
\hline
\end{tabular}

\section{Leading Pattern}

STAIN Majene has established a policy governing the prohibition of the use of the burqa/covering the face in the campus environment. Based on the Decree of the Chairman about the Pocket Book of the Students, the Lecturer Code of Ethics, the Code of Ethics of Educational Personnel, and the Committee on Enforcement of the Code of Ethics (KPKE). The leadership, faculty, and staff who joined in KPKE are given tasks and functions to implement the provisions of the supervision on an ongoing basis.

The policy on the code of conduct above is a response to the issue of religious and social morals with the emergence of harmful radical ideologies. So, the existence of the code of ethics is an instrument to train and form the academic community to become the individual characterized by Islamic values, and can be a role model for the community under the motto of the STAIN Majene "Superior and Malaqbiq".

The STAI DDI Majene has not set in writing about the ban on the use of face coverings in the campus environment in the Decision of the Chairman about the Student Code of Conduct. Abdullah stated that the attitude of the STAI DDI does not recommend or prohibit it either, however, for the academic services, students are required to open the face cover.

In the ethics of academic life, students STAI DDI are required to always obey and practice the Trilogy of DDI as well as making the regulations of the organization DDI as a guide and foundation in carrying out all activities and actions. 
STAI Al-Azhary is also in line with STAI DDI Majene in the issue of the burqa, until today STAI Al-Azhary has not issued a policy or a decision on banning the use of face coverings in both the Student Code of Conduct or Circular Letter. Syamsul said that the STAI Al-Azhary is not concerned about the use of the burqa, and do not agree with the stigma that the burqa is identical with radicalism, because it is the views, options, and beliefs of each individual, so we can not intervene in this belief segments.

Syamsul further explained that we have always appealed to all lecturers and education staff not to enter into the realm of such beliefs, and to be fair in providing academic services for students without any discrimination.

In harmony with the STAIN Majene, IAI DDI has written rules on the prohibition of using burqa for the student based on the Decision of the Rector of the Code of Conduct and the Student Code of Conduct. Firmly Anwar Sewang said that IAI DDI will be rebuked students who use the burqa and will not get any academic services.

From the information that we get, even though the policy embodied in the Ethical Code and the Student Code of conduct, every year the Rector issued a Circular regarding the prohibition of using face coverings for students.

Besides that, the IAI DDI apply the same rules as the STAI DDI Majene, as an organization that is also within the auspices of the DDI organization, the student is required to reflect the Trilogy of DDI in each activity.

\section{Strategies for Students Character Coaching in PTKI West Sulawesi}

In this section, the researchers tried to reconstruct the efforts of students ' character development that has been done by 4 (four) PTKI which became the locus of research in order to anticipate intolerant belief and radicalism. The reconstruction of this study refers to the concept of strategy by Martens (Martens, 2004, p. 58)in character development, namely: identify the values, teach the values, and apply the values.
Image. 1: Framework of the Reconstruction of Character Development Strategy of 4 PTKI

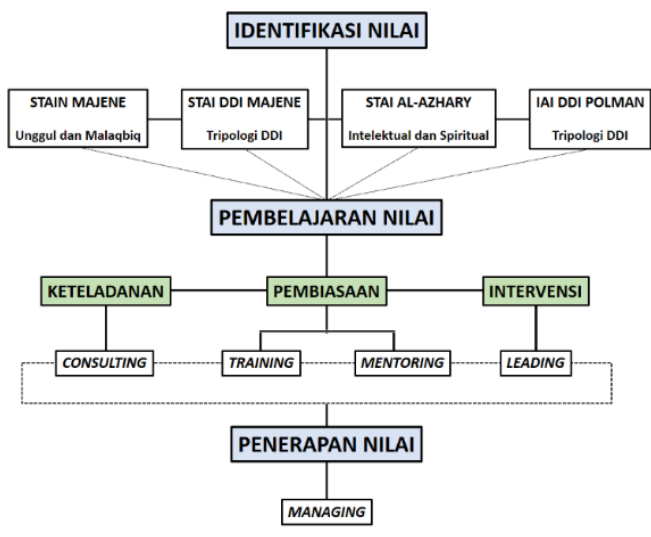

\section{Identify the Values}

From the results of the research findings, it is known that every PTKI above has had and specified the values that are oriented towards the achievement of the institutions' vision. The process of identifying these values are strongly influenced by culture and a social life that develop in the higher education environment.

The values developed by STAIN Majene are "Superior and Malaqbiq". The embedded word "Malaqbiq" in the vision of the STAIN Majene is a form of attention and high expectations to preserve the cultural values of the ancestors that developed in the Mandar community. So in the process of implementing the tri dharma of higher education, it is directed to comply with the values of religiosity and philosophy of malaqbiq, through the integration of academic morals, and social piety. While the word "Superior" shows the determination of STAIN Majene in producing, creating the alumni who are superior, top quality, competitive and innovative, have the competencies needed by the world of work and can be relied on for the betterment of the nation, religion, and country. (Pusat Penjamin Mutu, 2019, p. 17)

As the administrator of the college under the scope of the DDI Organization, STAI DDI Majene and IAI DDI Polman develop three main principles which are then formulated into a Trilogy of DDI that must be held and developed, namely: education, propaganda, and social. (Agama, 2001, p. 5) The establishment of Darud Da'wah Wal Irsyad term derived from Arabic which means the container of the struggle for da'wah and 
education so that the organization aims to build a society through the understanding of Islam that emphasizes Manhaj Ahlussunnah Wal Jama'ah through da'wah and education. (Galigo, n.d., p. 15)

In its history, the selection of the name Darud Da'wah Wal Irsyad that is followed by the formulation of a trilogy of DDI is a response to the scarcity of education due to the colonialism and the emergence of religious movements that are not tolerant to differences that could potentially cause conflict in society. Thus, the movement was created based on and held on to the values, teachings, and religious views of Ahlussunnah Wal Jama'ah which was then put under the name of DDI. (Yafie, n.d., p. 9)

As for the STAI Al-Azhary Mamuju, historically, it was a distant class of STAI DDI Polman. Although the establishment process is not affiliated with the DDI Organization, in practice, the motto of the DDI which espouses the value of Science, Faith, and Charity had inspired the existence of STAI Al-Azhary as a higher education institution that combines the competence on science, faith, and charity for all graduates. The value is reconstructed in the formulation of the institution vision into the intellectual and the spiritual values.

In his statement, Syamul said that intellectual and spiritual values are the reference in developing programs and activities on the STAI Al-Azhary to produce graduates who are competent, able to compete, have expertise in science, are professional, and can create an academic and religious environment.

From the description above, there is some distinction that is accentuated by each campus, STAIN Majene emphasis on the cultural aspects through "Malaqbiq", STAI DDI Majene and IAI DDI Polman emphasize social elements through the embedding of the word "al-da'wah", while the STAI Al-Azhary focusing on the aspects of religion that was reflected from the word "Spiritual". However, each campus is mainstreaming the education field contained in the word "Superior", "alIrsyad", and "Intellectual".

Concerning the moderation of religion, which is a program proposed to tackle the intolerant and radicalism, these values have to accommodate those content, although it is not explicitly stated.

In the Quality Standard of the STAIN Majene, (2019, pp. 80-88)it is noted that the point value of malaqbiq is an indicator derived from the construct of malaqbiq value which consists of spiritual depth, the grandeur of character, breadth of knowledge, as well as the professional maturity, through an approach that integrates the values of science, Islamic, Indonesian, and local wisdom of Mandar. In line with the STAIN Majene, Andi Syamsul Bahri, who now serves as the chairman of the DDI Organization Committee, explained that the purpose of the implementation of the trilogy of DDI is to find the middle way (manhaj wasathy) in anticipation the Islamic thought which flourished and give a negative impression to the values of Islam which is characterized by the emergence of various diverged ideologies. (Galigo, n.d., pp. 17-18) Similarly, the STAI Al-Azhary tries to combine science, faith, and charity for the realization of civil society. The attachment of "Civil" word that is listed in the vision of STAI Al-Azhary as presented by Syamsul, is the high expectations to develop graduates who believe in God, noble, highly civilized, uphold justice, tolerant, and able to balance between social rights and duties.

\section{Teach the Values}

Based on the identification of the values, the inculcation or teach those values through the methods of modelling, habituation, and intervention:

\section{a) Modelling}

In this context, the form of the modelling applied is the consulting pattern. It is been recognized that character development should be done by all of the elements in college together and in synergy. Thus, the lecturer as one of the important elements in this role should have integrity and be an example in behaving well in class or outside of class, whether to be appointed as an academic adviser or not.

From the findings, it is known that every PTKI above has a composed document that explains the role and function of an academic advisor. In the description of an academic advisor's role, it is only the STAIN Majene which plainly explains that the academic 
advisor is a model or example. Although the three other PTKI do not include the academic advisor roles, the outline in the other documents of each campus has accommodated that every lecturer (either the Academic Supervisor or not) should become a good example in behaving. As for the job/function description of an academic advisor, it is dominantly filled with academic and study aspects, however, the distinct aspects or characteristics that are reflected in the values as the orientation of each campus are also accommodated.

Concerning the mainstreaming moderation of religion through the prevention of intolerant, radicalism, as well as the formation of national identity, besides it has been contained in the distinctive values of each campus, each of the PTKI has adopted the content indirectly, and only IAI DDI which clearly emphasized the point.

\section{b) Habituation}

Habituation of moral value practice in the process of character development is done with a training and mentoring pattern. Through the process of education, lecturers are not only obliged to transform knowledge but also are required to be able to internalize the values and build the personality of the students. Therefore, as the efforts of mainstreaming moderation of religion that leads to resisting intolerant and radicalism, the coaching strategy conducted by PTKI is by integrating the nationalism subject, religious subjects, and the subjects characterized the higher education into the content of the curriculum.

Through this nationalism subject, students gain the knowledge and learning experiences to improve understanding and awareness about nationalism, civilized democracy, be a citizen who is competitive, disciplined, and actively participate in building a peaceful life based on the system of values of Pancasila.

Through religious subjects, students understand the universal values of Islam, the Islamic concept which is Rahmatan lil 'Alamin, as well as the concept of religiosity that is open to receive social reality that there are many human beings with their different choice of faiths and beliefs.

Through subjects that characterize the universities, STAIN Majene assign the subjects of Islam and local culture as an effort to internalize Islamic values into the culture and local wisdom. STAI DDI Majene and IAI DDI Polman assign subjects of DDI's values to determine the attitude and understanding of religion using manhaj wasathi namely ahlussunnah wal jamaah.

In addition to learning in the classroom, the process of transformation and internalization of character values is also done in the form of workshops, seminars, and public lectures. From the findings, the activities are mostly held by the STAIN Majene and IAI DDI Polman. In general, the issues which became the topic of discussion mostly led to the theme of strengthening national values, deradicalization, and the moderation of religion as a response to the problems of religion and nationality, which recently has started to be diminished due to the rise of ideologies that support the intolerant and violent actions.

The other variation applied in the process of value habituation is the mentoring pattern. The field observation found that every PTKI mentioned above has its own trending program in character development. Although there are differences in its application, generally it can be concluded that those programs lead to the strengthening of Arabic and English as well as the study of the sourcebook.

In practice, STAIN Majene implemented a program that leads to the strengthening of cultural values through Malaqbiq Character Building, STAI DDI Majene focus on the application of the Sima'an and Muhadatsah methods in improving the competence of a Foreign language, while IAI DDI Polman and STAI Al-Azhary accentuated the Students Boarding School Program or Ma'had al-jami'ah in order to develop the study of Islam.

Those religious activities are held to encourage students to become religious persons as well as govern the guidance of their religion with the best possible. Because one of the characteristics of a student with the best character is a devoutly religious student.

\section{c) Intervention}

The campus life regulation on PTKI above is reflected in the leading pattern which is the rector/chairman policy and regulations. 
From the results of the document study, in each PTKI, it is found the written rules related to the discipline of campus life for the entire community that consists of educators, staff, and students. These regulations include rights, obligations, violations and sanctions, including forbidding radicalism and intolerance belief.

The radicalism problem is a big problem faced by PTKI at this time. Thus, it takes policies that can prevent the existence and development of those beliefs. The PTKI in West Sulawesi has a different way of preventing radicalism. The methods were established in the hierarchical form from the leader policy of the ministerial institution, ranging from the Regulation of the Minister of Religious Affairs about the Statute of PTKIN, the Decision of the Directorate General of Islamic Education, and the Decision of the Rector/Chairman.

The Ministry of Religious Affairs of the Republic of Indonesia through the Directorate General of Islamic Education had issued a Circular Letter of the Director-General of Islamic Education, Number B3663.1/Dj.I/BA.02/10/2019 on 29 October 2019 about the Circular House of Religion Moderation. The circular letter is part of the implementation of policies that are committed to making moderation of practising religion as a part of the foundation of thinking, behaving, and the policy and program formulation in all stakeholders of the ministry of religious affairs, including PTKI.

Regarding this issue, the burqa/face cover for female students is still a polemic in PTKI West Sulawesi. There are differences in the way of addressing these issues, the STAIN Majene and IAI DDI Polman has released a regulation on the prohibition of using burqa in the campus environment, while the STAI AlAzhary and STAI DDI Majene did not question the issue and supported the implementation of freedom in practising the religion.

\section{Apply the Values}

In order to create the social and emotional experience which are related to the character values as a form of integration between the concepts and practices, it is necessary to create a space and opportunity for students to apply the value. From the findings, the strategy undertaken by PTKI above is formed in managing patterns.

The particulars are reflected in the character development form through Student Organizations (ORMAWA), which consists of the Student Executive Board (BEM) which is an executive agency at the level of universities or faculty, Student Association of the Department/Study Program(HMJ-PS) as the executive agency of the department or study program in improving the professionalism of filed competency, Student Representative Council (DPM) as a legislative body at the universities and department/faculty level, and the Interest and Talent Institution (LMB), which coordinate the Student Activity Unit (UKM) in developing the talent following the interests of each student.

In addition to the student activities which are coordinated by the universities institutionally in the improvement and development of the character through committee activities, lab practice, internship, and Community Service Program, there are also some student activities organized and held directly by the student organizations in the field of reasoning, interests and talents, as well as passions.

Based on the field notes, the institution and the student organization have been actively engaged in the effort to mainstream religious moderation through reasoning and science which are oriented on strengthening national values and de-radicalization of religious beliefs.

The various activities that are held by the students have indirectly become media and a place to build and hone their potential to have religious-spiritual intelligence, self-control, personality, intelligence, noble character, and skills needed by themselves, society, nation, and state.

In the state of the system, in general, it can be concluded that the four PTKI have been integrating academic activities (curricular) such as face to face lectures in the class with co-curricular activities such as reasoning through guest lectures, as well as extracurricular activities through the institution and student organizations. 


\section{CONCLUSION}

Based on the results of the previous analysis, the conclusions of this research can be formulated in the following description:

The strategy of students' character development at PTKI in West Sulawesi as the prevention efforts to tackle the intolerant and radicalism belief refers to the Marten strategy which includes 3 (three) stages, namely: identification of values, the teaching of values, and the application of values.

The three strategies which are carried out in an integrated way successfully create a pattern of development in the application form of training, consulting, mentoring, managing, and leading under the synergogy concept, which leads to the strengthening of the national knowledge and the deepening of religious understanding.

The application of the 5 (five) development patterns has formed a diverse paradigm of students that leads to a tolerant attitude so there is no indication of any intolerant and radical actions.

The existence of the values being implemented by each PTKI in West Sulawesi is a supporting factor in determining the direction of character development.

Mainstreaming moderation of practising religion in PTKI West Sulawesi is not only built through values as the basic guideline of each PTKI alone but it is also supported by the development of character-based curriculum, and regulations/policies that are formed in a hierarchy ranging from the Regulation of the Minister of Religion, the Decision of the General Directorate of Islamic Education, and the Decree of the Rector/Chairman who later became the order of life on campus as well as be a reference in the implementation of tri dharma in universities.

\section{REFERENCE}

Agama, D. (2001). Pola Penyelenggaraan Pondok Pesantren Ashriyhah. Jakarta: Proyek Peningkatan Pondok Pesantren.

Ali, M. (2013). Teologi Pluralis-Multikultural. Jakarta: Kompas.

Alimi, M. Y. (2018). Mediatisasi Agama PostTruth dan Ketahanan Nasional: Sosiologi Agama Era Digital (1st ed.). Yogyakarta: LKiS.
Amirsyah. (2012). Meluruskan Salah Paham Terhadap Deradikalisasi Pemikiran, Konsep dan Strategi Pelaksanaan (1st ed.). Jakarta: Grafindo Khazanah Ilmu.

Amirullah. (2018). Potensi Radikalisme di Sulawesi Barat 54 Persen. Retrieved August 15, 2019, from AntaraNews.com website: https://www antaranews.com

Anwas, O. M. (2010). Televisis Mendidik Karakter Bangsa: Harapan dan Tantangan. In Jurnal Pendidikan dan Kebudayaan, 16 no. 3 (Vol. 16, p. 258). Jakarta: Balitbang Kemendiknas.

Arif, S. (2016). Islam, Radikalisme dan Deradikalisasi Berbasis Pancasila. Societas Dei, 3(2), 240-267.

Arsyad, A., Jihad, S., Rasyid, A., Hasbuddin, H., \& Ab, I. (2003). Ke-DDI-an: Sejarah dan Pandangan Atas Isu-isu kontemporer (1st ed.; S. Pattinjo, Ed.). Yogyakarta: LKMP Pengurus Besar DDI dan The Asia Foundation.

BNPT: Sulbar Rawan Jadi Persinggahan Teroris. (2018). Retrieved August 15, 2019, from Kabar Indonesia ID website: https://www.kabarindonesia.id/berita/23 3/.html

Cahyani, F. T. (2011). Mahasiswa UIN Kaget Seniornya Terlibat Teroris. Retrieved September 27, 2019, from OKEZONE TV website: https://nasional.okezone.com/read/2011/ 04/24/337/449314/mahasiswa-uinkaget-seniornya-terlibat-teroris

Dja'far, A. M. (2018). (In)Toleransi! Memahami Kebencian \& Kekerasan Atas Nama Agama. Jakarta: PT Elex Media Komputindo.

Fadlilah. (2019). Perguruan Tinggi Berbasis Pesantren dan Perannya Dalam Deradikalisasi Agama. Falsafa, 10(1), 65-80.

Galigo, A. S. B. A. (n.d.). Ahli Sunnah Waljama'ah Simbol Fahaman Agama Tulen Sebagai Sistem Nilai Daru Da'wah Wal-Irsyad.

Harahap, S. (2017). Upaya Kolektif Mencegah Radikalisme \& Terorisme (1st ed.). Depok: Siraja.

Himpunan Peraturan Organisasi Darud Dakwah Wal-Irsyad. (2017). Makassar: Pengurus Besar DDI.

Idris, I. (2018). Deradikalisasi: Kebijakan, Strategi, dan Program Penanggulangan Terorisme (1st ed.). Jakarta: Cahaya Insani.

Institute, W. (2011). Lampu Merah Kebebasan Beragama: Laporan Kebebasan 
Beragama dan Toleransi di Indonesia (1st ed.). Jakarta: Wahid Institute dan Tifa Foundation.

Kesra, M. (2010). Desain Induk Pengembangan Pendidikan Karakter Bangsa 2010-2015. Jakarta: Pemerintah Republik Indonesia.

Kisbiyanto. (2016). Manajemen Kurikulum Dalam Perspektif Anti-Radikalisme. Addin, 10(1), 181-206.

Kontri. (2018). Pimpinan Ormawa PTKIN Harus Terdepan Lawan Radikalisme. Retrieved September 26, 2019, from Kemenag.go.id website: https://kemenag.go.id/berita/read/50793 6/pimpinan-ormawa-ptkin-harusterdepan-lawan-radikalisme

Lickona, T. (1992). Educating for Character: How Our Schools Can Teach Respect and Responsibility. New York: Bantam Book.

Maarif, A. S. (2002). Islam and The Challenge of Managing Globalisation. Washington DC: Trilateral Commission Task Force Meeting on Islam and Globalisation.

Majene, S. (2019). Buku Saku Mahasiswa. Majene: STAIN Majene.

Martens, R. (2004). Successful Coaching (3rd ed.). Champaign: Human Kinetics.

Megawani, R. (2007). Pendidikan Karakter Solusi Yang Tepat Untuk Membangun Bangsa (2nd ed.). Jakarta: Indonesia Heritage Foundation.

Mudzhar, M. A. (2011). Islam in Globalized World - The Challenges of Human Rights, Law, and Interfaith Harmony. Jakarta: Badan Litbang dan Diklat Kementerian Agama.

Muhtarom, A., Karim, A., Choiron, A., Asmani, J. M., \& Hasyim, Y. (2018). Islam Agama Cinta Damai, Upaya Menepis Radikalisme Beragama (1st ed.; J. M. Asmani, Ed.). Semarang: CV. Pilar Nusantara.

Mukhibat. (2015). Dalam Mememutus Mata Rantai Radikalisme dan Terorisme Berbasis Studi Etnopedagogi di PTNU Dalam Membentuk Keberagaman Inklusif dan Pluralis. ISLAMICA: Jurnal Studi Keislaman, 10(Sept), 222-247.

Mutu, Pusat Panjaminan. (2019). Pedoman Edukasi STAIN Majene. Majene: STAIN Majene.

Mutu, Pusat Penjamin. (2019). Standar Mutu Sekolah Tinggi Agama Islam Negeri Majene. Majene: STAIN Majene.

Mutu, Pusat Penjaminan. (2019). Pedoman Penasehat Akademik STAIN Majene.
Majene: STAIN Majene.

Panduan Akademik Institut Agama Islam Darud Dakwah Wal-Irsyad (IAI-DDI) Polewali Mandar. (2016). Polewali Mandar: IAI DDI Polman.

Panduan Akademik Sekolah Tinggi Agama Islam Darud Dakwah Wal-Irsyad Majene. (2017). Majene: STAI DDI Majene.

Pedoman Akademik Sekolah Tinggi Agama Islam Al-Azhary Maтиju. (2016). Mamuju: STAI Al-Azhary Mamuju.

Republik Indonesia, K. A. (2010). Toleransi Beragama Mahasiswa (1st ed.; $\mathrm{H}$. Bahari, Ed.). Jakarta: Badan Litbang dan Diklat Kementerian Agama.

Rights, O. of T. H. C. for H. (n.d.). Human Rights: A Basic Handbook for UN Staff. United Nations.

Rochmanuddin. (2018). Mahasiswi IAIN Tulungagung Diduga Terlibat ISIS, Orangtua Depresi. Retrieved September 26, 2019, from IDN Times website: https://www.idntimes.com/news/indones ia/rochmanudin-wijaya/mahasiswi-iaintulungagung-diduga-terlibat-isisorangtua-depresi

Rokhmad, A. (2012). Radikalisme Islam dan Upaya Deradikalisasi Paham Radikal. Walisongo, 20(1), 79-114.

Saputra, R. E. (2018). Api Dalam Sekam. 1(1). Semua Kampus PTKI Mendirikan Rumah Moderasi Beragama. (2019). Retrieved July 14, 2020, from Direktorat Jenderal Pendidikan Islam website: http://www.pendis.kemenag.go.id/index. php?a=detil\&id=10972\#.X0YPCjYzbIU Sinambela, F. C. (2002). Sinergogy: Mencari Model Pendampingan Alternatif dalam Membangun Karakter Bangsa. LokaKarya Nasional Pendamping/Pembina Kemahasiswaan, 1(1).

Soetanto, H., Aulanni'am, Guritno, B., \& Suharto, B. (2013). Model Pendidikan Karakter Menuju Entrepreneurial University di Universitas Brawijaya (1st ed.). Malang: Universitas Brawijaya Press.

Sudjana, N. (2010). Penilaian Hasil Proses Belajar Mengajar. Bandung: PT Remaja Rosdakarya.

Suharto, T., \& Assagaf, J. (2014). Membendung Arus Paham Keagamaan Radikal Di Kalangan Mahasiswa PTKIN. Al-Tahrir, 14(1), 157-180. https://doi.org/https://doi.org/10.21154/a 1-tahrir.v14i1.72 
Sumaryanto. (2002). Optimalisasi Pembinaan Kegiatan Kemahasiswaan Untuk Menciptakan Mahasiswa Unggul. Cakrawala Pendidikan, 21(2), 238-250. Unesco. (1994). Tolerance: The Threshold of Peace A Teaching/Learning Guide for Education for Peace, Human Rights and Democracy. Paris: Unesco.

Wahab, A. J. (2019). Islam Radikal dan Moderat: Diskursus dan Kontestasi Varian Islam Indonesia (1st ed.). Jakarta: PT Gramedia.

Wijaya, A., \& dkk. (2020). Berislam di Jalur Tengah (1st ed.; A. Wijaya \& A. Y. Elga, Eds.). Yogyakarta: IRCiSod.
Winarni, S. (2013). Integrasi Pendidikan Karakter Dalam Perkuliahan. Jurnal Pendidikan Karakter, 3(1), 96-97.

Wismabrata, M. (2016). Kampus Ancam DO Terduga Teroris KF. Retrieved September 26, 2019, from Kompas.com website:

https://regional.kompas.com/read/2016/ 12/13/14072621/kampus.ancam.do.terdu ga.teroris.kf

Yafie, H. A. (n.d.). Gerakan Pendidikan dan Dakwah Gurutta Ambodalle.

Zubaedi. (2011). Desain Pendidikan Karakter: Konsepsi dan Aplikasinya Dalam Lembaga Pendidikan (1st ed.). Jakarta: Kencana. 